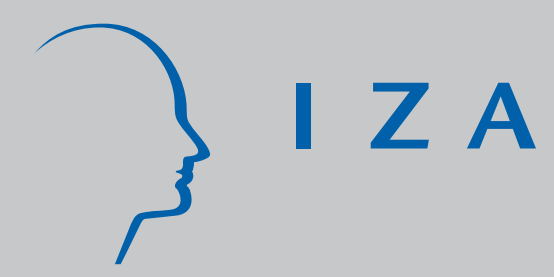

IZA DP No. 294

Estimating the Effect of Unemployment Insurance Compensation on the Labor Market Histories of Displaced Workers

Stepán J uraj da

May 2001 


\title{
Estimating the Effect of Unemployment Insurance Compensation on the Labor Market Histories of Displaced Workers
}

\author{
Štěpán Jurajda \\ CERGE-EI, CEPR, WDI and IZA, Bonn
}

Discussion Paper No. 294
May 2001

IZA

P.O. Box 7240

D-53072 Bonn

Germany

Tel.: +49-228-3894-0

Fax: +49-228-3894-210

Email: iza@iza.org

This Discussion Paper is issued within the framework of IZA's research area The Welfare State and Labor Markets. Any opinions expressed here are those of the author(s) and not those of the institute. Research disseminated by IZA may include views on policy, but the institute itself takes no institutional policy positions.

The Institute for the Study of Labor (IZA) in Bonn is a local and virtual international research center and a place of communication between science, politics and business. IZA is an independent, nonprofit limited liability company (Gesellschaft mit beschränkter Haftung) supported by the Deutsche Post AG. The center is associated with the University of Bonn and offers a stimulating research environment through its research networks, research support, and visitors and doctoral programs. IZA engages in (i) original and internationally competitive research in all fields of labor economics, (ii) development of policy concepts, and (iii) dissemination of research results and concepts to the interested public. The current research program deals with (1) mobility and flexibility of labor markets, (2) internationalization of labor markets and European integration, (3) the welfare state and labor markets, (4) labor markets in transition, (5) the future of work, (6) project evaluation and (7) general labor economics.

IZA Discussion Papers often represent preliminary work and are circulated to encourage discussion. Citation of such a paper should account for its provisional character. 
IZA Discussion Paper No. 294

May 2001

\title{
ABSTRACT \\ Estimating the Effect of Unemployment Insurance Compensation on the Labor Market Histories of Displaced Workers*
}

In this paper, U.S. data on labor market histories of displaced workers are used to quantify the effect of Unemployment Insurance Compensation (UIC) on both unemployment and employment durations. This results in the first available assessment of the effect that UIC has on the fraction of time spent employed. The estimation procedure simultaneously allows for unobserved heterogeneity, defective risks and sample selection into future spells, and uses alternative assumptions about agents' knowledge of the UIC eligibility rules. Being entitled to UIC shortens workers' employment durations. This negative effect on the fraction of time spent employed could be offset by suspending an extended benefits program in order to shorten unemployment durations.

JEL Classification: C41, J63, J65

Keywords: Employment durations; unemployment insurance; unmeasured heterogeneity; defective risks; sample selection

\author{
Štěpán Jurajda \\ CERGE-EI \\ POB 882 \\ Politickych veznu 7 \\ Prague 1, 11121 \\ Czech Republic \\ Tel.: +420-2-24005 139 \\ Fax.:+420-2-242 11374 \\ E-mail: stepan.jurajda@cerge.cuni.cz
}

\footnotetext{
* A joint workplace of the Center for Economic Research and Graduate Education, Charles University, and the Economics Institute of the Academy of Science of the Czech Republic.
} 


\section{Introduction}

While there have been numerous studies estimating the effect of unemployment insurance compensation (UIC) on duration of unemployment, there has been no empirical work analyzing the effect of UIC on employment durations in the United States. ${ }^{1}$ This gap in the literature is somewhat surprising since there are at least two theoretical arguments for why we would expect UIC to affect employment durations. First, the implicit contract literature suggests that unemployment insurance makes layoffs more likely (e.g., Feldstein, 1976; Baily, 1977). Second, job search models suggest that workers with generous UI coverage will search less intensively while unemployed. As we discuss in section 3, one can show that the optimal firm response to this behavior, in the presence of demand fluctuations and firm specific human capital, is for the firm to lay off workers with high levels of UI entitlement and recall workers as they approach exhaustion of their benefits.

Hence, generous UIC may not only prolong unemployment (e.g., Mortensen, 1977), but also shorten employment duration, reinforcing the combined negative effect of UIC on the fraction of time spent employed. To see this in a simple setting, consider the steady state probability of being employed, $P_{e}$, which can be written as

$$
P_{e}=\frac{E_{e}}{E_{e}+E_{u}}
$$

where $E_{e}$ is the expected duration of employment and $E_{u}$ denotes the expected duration of unemployment, both being functions of the level of UIC. It follows that

$$
\frac{\partial P_{e}}{\partial U I C}=\left[E_{e}+E_{u}\right]^{-2} \frac{\partial E_{e}}{\partial U I C} E_{u}-\frac{\partial E_{u}}{\partial U I C} E_{e}
$$

Evaluating unemployment insurance based on only the existing (positive) estimates of its effect on unemployment duration $\frac{\partial E_{u}}{\partial U I C}$ may therefore result in underestimating the total impact of UIC.

\footnotetext{
${ }^{1}$ The only studies looking at employment durations we are aware of are Baker and Rea (1998) and Christofides and McKenna (1996). Both analyze the effect of Canadian UI eligibility requirements. There is extensive research in the U.S. using cross-sectional data to analyze the layoff effect of unemployment insurance taxes. We discuss this work in section 2; analyzing this issue, however, is beyond the scope of the present paper. As we explain below, the amount of potential UIC a worker can expect to receive varies over the duration of individual employment spells; hence, the need to use duration data.
} 
In this paper we therefore quantify the effect of UIC on both unemployment inflow and outflow using a micro data set on labor market histories of U.S. workers. As a result, we obtain the first available assessment of the effect UIC has on the fraction of time spent employed. Relaxing the steady state assumption used above, we quantify the overall effect of UIC by simulating the process of finding and losing jobs for all individuals in our data under different levels of UIC.

The lack of research on the UIC employment duration effect is likely caused by the fact that large micro data sets on employment durations and UI compensation are scarce. We use a data set which consists of a dislocated workers' survey, augmented with information on the amount of UI compensation individuals can expect to receive if they are laid off or quit. Unemployment compensation provisions, including the trigger dates of various extended benefit programs, are coded for over five years for seven states. The resulting multiple-spell, event-history data set is unusually rich in terms of the variation of entitlement and benefit levels.

The use of hazard models in analyzing duration data has become widespread, and accounting for unobserved heterogeneity is now a standard part of hazard estimation sensitivity analysis. The estimation procedure used here allows for the effects of unobserved heterogeneity in a number of ways and controls for sample selection into multiple spells, a potentially important issue in the estimation of duration models: Using multiple-spell data on employment and unemployment durations provides greater variation and improves identification of the unobserved heterogeneity distribution (Heckman and Singer, 1984). The use of this type of data, however, also raises the possibility of selection bias: i.e., the workers who have multiple employment spells may be a nonrandom sample. To control for this problem, we estimate employment and unemployment durations jointly while allowing the unobserved heterogeneity to be correlated across these spells. ${ }^{2}$

The estimation of employment duration effects of UIC also requires a separate focus on different

\footnotetext{
${ }^{2}$ For a similar approach and for a discussion of dynamic sample selection in multiple-state, multiple-spell data, see Ham and Lalonde (1996). They find important sample-selection bias when estimating the effect of classroom training on employment histories of disadvantaged women. In the present study, the level and availability of UIC depends on workers' employment histories. To the extent that employment histories are driven by unobservables, this may introduce dependence between UIC and unobservable heterogeneity, biasing the estimation of the UIC effects.
} 
ways of exiting an employment spell. A worker who quits will generally not be entitled to UI compensation. In the presence of a positive layoff probability, delaying a quit to non-employment will provide the worker with a chance of getting laid off and obtaining UI coverage. Thus, one may expect the opposite entitlement effects when comparing layoff and quit decisions, which motivates a separate analysis of quits and layoffs in a competing risk duration model. The richest estimated model is therefore a multiple-spell, multiple-state competing risk duration model with unobserved heterogeneity. Finally, the estimated unobserved heterogeneity models naturally extend to account for the possibility of defective risks (zero probability of a quit for a fraction of the sample).

The theory modeling worker (firm) response to UIC is forward-looking: it evaluates future streams of income (profit). The nature of the UIC system, however, makes it hard to predict future level and availability of UIC, which depend on individual labor market histories as well as on the evolution of the labor market. Any attempt to evaluate the effects of UIC on economic outcomes therefore has to rely on arbitrary assumptions about how agents form expectations of the available UI compensation. ${ }^{3}$ In this paper, we examine the robustness of the empirical results with respect to different assumptions about how firms and workers account for UIC rules when determining eligibility for future UI claims. This issue has not been addressed previously. The type of assumption one makes in the estimation significantly affects the levels of the explanatory variable of interest-UI entitlement. In the empirical analysis we therefore compare results based on the assumption that future UI eligibility is ignored to results based on the assumption that future UI eligibility is taken into account.

The empirical results suggest that being entitled to UI compensation significantly increases the layoff hazard (defined as the probability of getting laid off in a given week conditional on being employed up to that week). In contrast to theoretical prediction, however, neither the length of

\footnotetext{
${ }^{3}$ For example, the availability of extended UI benefits depends on the evolution of the state (insured) unemployment rate. Rogers (1998) estimates the UIC effect on unemployment outflow (hazard) and examines the robustness of the estimates with respect to different assumptions about agents' expectations. Her results imply that workers have significant, although not perfect, foresight about changes in UI provisions.
} 
potential UI entitlement nor the dollar amount of UI benefits, conditional on being positive, affect the layoff hazard. The quit hazard is not affected by any of the UI system parameters. Findings on the UI effect on unemployment outflow are in accord with the existing literature.

To measure the magnitude of the estimated UIC effects, we study the fraction of time (sampling frame) spent in employment under various policy experiments. This exercise suggests that the positive UIC layoff effect, which shortens employment durations and lowers the fraction of time spent employed, could (roughly) be offset by shortening of unemployment durations corresponding to suspending an extended benefits program. (See Section 4 for definitions of extended benefits programs.)

The paper proceeds as follows. Section 2 discusses previous work and Section 3 models firm employment decisions. The data set is described in Section 4. Section 5 presents the econometric approach together with the empirical results. Section 6 concludes.

\section{Previous Work}

There is a large volume of research, based on the optimal job search theory (Mortensen, 1977), analyzing the effect of UIC on the duration of unemployment. For a survey of the search-theoretic empirical literature, see Devine and Kiefer (1991). The strand of economic literature focusing on (temporary) layoffs and unemployment insurance, however, is smaller in volume. It starts with the analyses of implicit contract models by Feldstein (1976) and Baily (1977). In these models, firms facing competitive labor markets have to offer employment contracts which provide workers with a market-determined level of expected utility. While Feldstein's 1976 model focuses on the role of imperfect experience rating of firms in the presence of product demand fluctuations, ${ }^{4}$ Baily (1977) shows that increases in the level of UIC cause firms to increase layoffs: Since workers with UI coverage are better protected against prolonged spells of unemployment, the layoff probability

\footnotetext{
${ }^{4}$ The U.S. system of levying unemployment insurance tax based on an employer's unemployment experience is called experience rating.
} 
becomes an increasing function of UIC. ${ }^{5}$

Implicit contract models assume workers' utility level is exogenous and endogenize the level of wages. On the other hand, models focusing on the adjustment cost aspect of UI taxes ${ }^{6}$ (e.g., Card and Levine, 1992) take wages as exogenous. Firms are at least partially responsible for UI benefits paid to their former employees. A typical adjustment cost model would therefore imply that more generous UI coverage leads to lower risks of layoff, contrary to predictions of implicit contract models. Anderson and Meyer (1994) extend the adjustment cost model to include the compensation package concept of implicit contract models. While all models predict a negative relation between the degree of experience rating and layoffs, their analysis allows for different effects of UIC.

The theoretical work discussed above has motivated a number of empirical studies focusing on experience rating. Typically, these studies use CPS cross-sectional data sets (e.g., Topel, 1983; Card and Levine, 1992) and suggest that the unemployment inflow effect of UI is potentially quite large because of imperfect experience rating. Anderson and Meyer (1994) analyze cross-sectional data sets based on the Continuous Wage and Benefit History (CWBH) survey to quantify the effects of experience rating and the level of potential UI coverage on the incidence of layoffs. While they confirm previous findings of large experience-rating effects, they obtain conflicting estimates of the effect of potential UI coverage.

Baker and Rea (1993) and Christofides and McKenna (1996) analyze the effect of Canadian UI eligibility rules to identify spikes in the employment hazard (i.e., the hazard of leaving employment) in the first week of eligibility. Canadian eligibility rules depend on local economic conditions, but Baker and Rea (1993) are able to untangle this dependency by using a unique change in the eligibility formula orthogonal to changes in the economic environment. Their results indicate a significant increase in the employment hazard in the week in which individuals qualify for UI compensation.

\footnotetext{
${ }^{5}$ The implicit contract analysis is generalized by Burdett and Hool (1983), who incorporate the optimal contract determination into a bargaining problem of firms and workers, and by Haltiwanger (1984), who analyzes a multiperiod contract model allowing for the interaction of stock adjustment and factor utilization decisions.

${ }^{6} \mathrm{UI}$ taxes make employment adjustment costly because of experience rating.
} 
Other than including three dummy variables capturing UI eligibility, ${ }^{7}$ they do not control for the level of available UI compensation. In particular, they do not control for the dollar amount of UI benefits available and for changes in the maximum amount of UI entitlement.

This paper extends the existing literature by analyzing the effect of UI on employment durations in the U.S., using different, rich sources of variation in UI compensation ${ }^{8}$ and considering quits and layoffs separately.

\section{A Dynamic Model of Layoffs ${ }^{9}$}

Consider a dynamic decision problem of a price-taking, profit-maximizing firm deciding on the employment status of a fixed roster of workers. ${ }^{10}$ Wages are fixed at $w$ and the firm faces demand fluctuations assumed to take the form of i.i.d. draws from a firm-specific distribution of marginal revenue product $M$ of its workers. Workers differ only in their UI entitlement, measured in length of available benefits collection. An employed worker brings the firm a per-period profit of $M-w$. A laid off worker collects UIC until benefits lapse. He may either be recalled or accept a position with a different employer. If the firm finds it profitable to replace a worker lost to another employer with a new worker, it incurs training costs. The key assumption is that a laid off worker follows the optimal job search strategy (Mortensen, 1977), which is known to the firm. ${ }^{11}$

Based on these assumptions and appealing to Bellman's principle of optimality, one can define the firm's profit value function from having a worker employed. Since the function is monotonically increasing in the value of marginal revenue product $M$, there is an optimal layoff stopping rule $m$,

\footnotetext{
${ }^{7}$ The first one equals one in the week when a given worker becomes eligible. The second indicates that the worker's entitlement is between the minimum and maximum value. The third dummy variable equals one when the worker has attained the maximum potential entitlement.

${ }^{8}$ Anderson and Meyer (1994) use state variation in entitlement and benefits coming from the high quarter wage and base period earnings, which together with the state level of the maximum benefit amount are used to determine regular benefit amount and duration.

${ }^{9}$ This section is a simplified non-technical summary of a dynamic optimization problem analyzed in Jurajda (2000).

${ }^{10} \mathrm{~A}$ similar assumption of a fixed roster of workers was used in most previous studies, e.g. Feldstein (1976) and Card and Levine (1992), to narrow the model's focus to temporary layoffs. The workers are attached to the firm through firm-specific training.

${ }^{11}$ The important maintained assumption is that workers do not take the optimal recall strategy of firms into account when optimizing their search behavior.
} 
such that the firm decides to keep the worker at all $M \geq m$ and to lay off otherwise. ${ }^{12}$ Similarly, one can write a profit value function from having a worker on layoff. The optimal layoff stopping value of marginal revenue product $m$ is then implicitly defined by the equality of the profit value functions in the two states, employment and unemployment, evaluated at the optimal stopping rule. That is, at $M=m$, the firm is indifferent between laying off or retaining a worker.

This implicit definition can be used to study properties of the optimal decision rule $m$. A standard result from the job search literature is that the probability of a worker on layoff finding a job with a firm is a decreasing function of the length of the remaining UI entitlement period. Hence, assuming that the firm takes workers' search strategies into account, laying off a worker with a high value of potential UI entitlement is less costly for the firm since such a worker will be less likely to find a new acceptable job with an alternative employer. One can therefore show that the per-period layoff probability increases with the level of UIC entitlement, motivating layoff hazard estimation of the UIC effect much the way job search models motivate estimation of (new job) unemployment hazards. ${ }^{13}$

A worker who quits will generally not be entitled to UI compensation, and so one might expect opposite entitlement effects when comparing layoff and quit decisions: Clearly, there will be no effect of UI compensation on job-to-job quits. Quits to non-employment are present in the job matching models (e.g., Jovanovic 1979). If there is a positive probability of getting laid off, it could pay off for a worker contemplating a quit to non-employment to stay employed one more period, since by doing so he could get laid off and be qualified for UI coverage. The higher the available UI compensation, the stronger the incentive to wait for (or induce) layoff. Workers with high entitlement can therefore be expected to be less likely to quit.

\footnotetext{
${ }^{12}$ The value function consists of the per-period profit rate $\mathbf{M}-\mathbf{w}$ and the discounted future profits in three possible states, weighted by their respective probability: First, if there is no change in $M$, the firm faces a similar optimization problem next period. Second, the firm evaluates the expected profits resulting from employing a worker at a newly arriving value of $M$ above the layoff threshold $m$. Third, when a below-the-threshold value of $M$ arrives, the worker is laid off and the firm expects to receive the profit value function from having a worker unemployed.

${ }^{13}$ Similarly, one can show that it is optimal for the firm to recall workers with higher probability as they approach exhaustion of their benefits, providing motivation for recall hazard estimation.
} 


\section{Data Description}

The data employed in this paper come from the Trade Adjustment Assistance (TAA) Survey. Implemented in 1974, the TAA program was intended to compensate workers harmed by market fluctuations resulting from a rise in imports. ${ }^{14}$ The data was collected from retrospective interviews with individuals who became unemployed in the mid 1970s. This information was merged with UI claims records. The data comes from seven states ${ }^{15}$ and covers the period up to 1979. The TAA recipients were entitled to extensions of the regular UI entitlement of up to 52 weeks. Also, their replacement ratio (i.e. the ratio of UI benefits to wages on the last job) was set at $70 \%$ as opposed to the $50 \%$ typical of regular UI. Both regular UI recipients and TAA recipients are included in the sample. ${ }^{16}$ The combination of TAA and UI recipients leads to a rich variation in UI entitlement and benefits. The other attractive feature of this sample is that it covers a period with many dramatic changes in UI entitlement, caused by various extended coverage programs being triggered on and off. Further, with the exception of the Survey of Income and Program Participation (SIPP), it appears to be the only U.S. data set on employment durations.

During the sample period there were two types of extended coverage programs in effect: the Extended Benefits program and the Federal Supplemental Benefits program. These programs trigger on and off based on state and national insured unemployment rates. The State-federal Extended Benefits program triggers both at state and national levels and adds up to 13 weeks of UI benefits ( $50 \%$ beyond the state potential duration). The Federal Supplemental Benefits program extended the previous entitlement by up to 26 additional weeks of UI compensation. It was enacted at the national level and the number of extra weeks of UI differed both across states and over time. ${ }^{17}$ The two programs could therefore change the typical 26 weeks of regular UI entitlement by as much as 39 weeks. Most of the empirical leverage necessary for the identification of the entitlement effect

\footnotetext{
${ }^{14}$ The program was amended several times and is still active.

${ }^{15}$ California, Indiana, Massachusetts, New York, Ohio, Pennsylvania and Virginia.

${ }^{16}$ For a thorough description of the data and for information about the TAA program, see Corson and Nicholson (1981).

${ }^{17}$ A brief description of these programs can be found in Jurajda (1997).
} 
comes from these programs, as well as from the combination of UI and TAA recipients.

Note that potential entitlement can also be quite low in some cases. Consider a worker who is recalled or finds a new job only a few weeks prior to exhausting UI benefits. Before he accumulates enough earnings to be eligible for the full UI entitlement, the worker faces the possibility of layoff with a low value of entitlement left from the previous spell of unemployment. Hence, the existence of the UI benefit year is another source of variation in potential entitlement. The UI benefit year starts when a UI claim is filed, at which moment the initial entitlement is determined based on the eligibility requirements. If a worker becomes employed after a few weeks of unemployment, a large amount of entitlement remains available for the duration of the UI benefit year. However, potential entitlement for those workers with only a few weeks left in their UI benefit year can be less than the remaining (non-collected) part of their initial entitlement. Hence, potential entitlement can also vary with time left in a UI benefit year.

From the initial sample of 1,501 men and women we work with the subsample of 953 men. We drop 102 cases in which the initial unemployment spell was in fact a period of reduced hours and 14 workers who do not start an employment spell during the sample frame. ${ }^{18}$ Finally, inconsistent and missing data records were deleted, yielding a sample of 808 men, of which $62 \%$ collect TAA in the initial unemployment spell. The data is recorded for a period of about 3.5 years for each individual and includes no simultaneous job holdings. The initial spell of unemployment is followed by an employment spell for all 808 workers. Approximately $50 \%$ of the first employment spells are censored and about half of the subsequent unemployment spells end in another employment spell. Moreover, about $10 \%$ of workers experience three employment spells within the sample frame; these individuals have lower than average durations of both unemployment and employment. ${ }^{19}$ The existence of this group of workers with short employment and unemployment durations suggests the

\footnotetext{
${ }^{18}$ These 14 workers report being out of the labor force at the time of the interview. This raises a sample selection issue as they may have been active job seekers when they first lost their job. However, given the small number of such workers, this issue is not explored in the empirical analysis.

${ }^{19}$ Only about $10 \%$ of those who enter second and third jobs are construction workers.
} 
possibility of substantial unobserved heterogeneity correlated across spells and states and affecting the selection into multiple spells. Such dynamic sample selection (on unobservables) may correlate unobservable heterogeneity with the UIC variables because the UI eligibility rules make the available UI compensation depend on workers' labor market histories. This issue (of potential bias in estimating the UIC effects) will be explored in the empirical analysis.

Table 1 shows the data means at the first week of spells for all 808 men. The averages for unemployment spell benefits and entitlement in the current UI claim are taken over UI recipients only. The non-recipients consist primarily of people who have quit their previous jobs. The low average values of UI benefits and entitlement in the first week of employment spells come from the fact that, at the beginning of a spell, individuals are sometimes not eligible for UI compensation. The reported standard deviations of the UI variables reflect only the cross-sectional variation in the first week of each spell. Additional time variation used in the estimation comes mostly from the extended coverage programs, which change the amount of available compensation even for spells in progress.

The simplest approximation to the underlying hazard functions which ignores both observed and unobserved differences in the population is provided by the Kaplan-Meier empirical hazards. A basic set of empirical hazards is presented in Appendix 6, which contains the overall unemployment empirical hazard with one standard deviation bounds. It also presents empirical hazards for the employment spells (overall and competing risks), and reveals differences between layoffs and quits (the layoff hazard is larger than quit hazard in the first 40 weeks of duration) as well as spikes at approximately one year of duration, reflecting perhaps the end of a probation period or recall bias. $^{20}$

The data set contains information on the level of initial entitlement and benefits only for the first unemployment spell. We impute both (i) the potential entitlement for the employment spells

\footnotetext{
${ }^{20}$ Recall bias occurs when individuals who do not recall the exact duration of their employment spell report approximate duration rounded to the closest six-month period, for example.
} 
and (ii) the actual entitlement levels for the second and third unemployment spell from the state specific UI laws and the individual data. To impute the UI compensation, we use the level of initial entitlement in the first unemployment spell and follow each individual over time, determining the level of entitlement in each week based on the individual's employment history, information on the reason for job separation (i.e. quit as opposed to layoff ${ }^{21}$ ), UI eligibility requirements, and the effective trigger dates of extended benefits programs. In the imputation procedure we assume that workers file UI claims whenever they are entitled to do so. When determining eligibility we also assume that wages do not change on the job (only accepted wages are reported). ${ }^{22}$

Using predicted values of UI entitlement instead of actual ones is a potential drawback of the data. Note, however, that workers or firms contemplating a transition out of employment will have to use their own prediction of potential entitlement based on a similar information set. Thus, we would argue that our prediction of the potential UI compensation should not significantly affect the results, at least in the employment spells.

One important question arising when imputing potential entitlement values is whether workers and firms are able to determine the UI eligibility for future UI claims. For example, is a recently recalled worker with only 10 weeks of entitlement left from his spell of unemployment able to predict that if he were laid off at that time, he would (after exhausting the remaining 10 weeks of entitlement) become eligible for another UI claim? If so, then the value of potential entitlement should equal the sum of the remaining UI compensation from the existing UI claim, plus the initial UI entitlement a newly eligible worker would obtain at the beginning of a new UI claim. This assumption on potential entitlement seems reasonable since all of the workers in the sample went through the process of filing the initial UI claim at the beginning of the sample frame and, therefore, should have at least some understanding of what the UI eligibility requirements are. Similarly, firms can be assumed to know the UI rules as they face layoff decisions on a regular basis. Assuming that

\footnotetext{
${ }^{21}$ There were only a few cases of an individual being fired for cause, and they are omitted in the empirical analysis.

${ }^{22}$ The information sources used in imputing UI compensation are listed in Jurajda (1997).
} 
UI eligibility rules are well known, a recently recalled worker who becomes eligible for a new UI claim during his current UI claim will have higher potential UI entitlement than a worker who has been on a job for over one year. Taking future repeated UI claims into account therefore breaks the usual positive relationship between the level of potential UI entitlement and job duration. On the other hand, it may be that firms and especially workers are somewhat myopic in measuring potential UI entitlement. In the estimation we therefore allow for alternative assumptions on whether individuals account for UI eligibility rules when determining future entitlement.

\section{Estimation and Results}

A typical job search model derives the per period escape rate out of unemployment as a function of the remaining UIC. Job search models therefore naturally motivate the estimation of unemployment hazard functions, which parametrize the probability of leaving unemployment at each time period. Similarly, estimation of the employment quit process has been motivated by on-the-job search models (e.g., Burdett 1978). Finally, the model of layoff decisions discussed in Section 3 derives the optimal per period layoff rate as a function of the UIC and motivates estimation of a layoff hazard function. The reduced-form hazard model used here therefore estimates the conditional probability of (i) finding a job while unemployed or (ii) losing a job while employed. The resulting estimates for employment or unemployment durations can be interpreted as approximations to the comparative statics implied by a corresponding model of job separations or job search. The theoretical considerations presented in Section 3 also point to a differential effect of UI on quits and layoffs and lead to a competing risks estimation of employment hazard functions. ${ }^{23}$

\subsection{Econometric Model}

The duration model builds upon the concept of a hazard function, which is defined as the probability of leaving a given state at duration $t$ conditional upon staying there up to that point. Using this

\footnotetext{
${ }^{23}$ In the unemployment hazard we do not differentiate between recalls and new job findings since this issue has been analyzed extensively in the existing literature (e.g., Katz and Meyer, 1990).
} 
definition one can build a likelihood function for the observed durations and estimate it using standard methods. However, it is well known that in the presence of unobserved person specific characteristics affecting the probability of exit, all of the estimated coefficients will be biased. To control for unobserved factors, we follow the flexible approach of Heckman and Singer (1984). The strategy is to approximate any underlying distribution function of unobservables by estimating a discrete mixing distribution $p(\theta)$ of an unobserved heterogeneity term $\theta$ as a part of the optimization problem.

More specifically, let $\lambda_{j}\left(t, x_{t} \mid \theta_{k}^{j}\right)$ be the conditional probability (hazard) of leaving a given state at time (duration) $t$ for someone with person specific characteristics $x_{t}$, conditional upon this person having the unobserved factor $\theta_{k}^{j}, k=1,2, \ldots, N_{\theta}^{j}$. The $j$ subscript stands for the different ways of leaving a given state and serves, therefore, as a state subscript as well. For example one can leave employment through a quit or through a layoff, in which case $j \in\{q, l\}$. This is often referred to as a competing risk model. In what follows, we work in discrete time with weekly hazards in logit specification:

$$
\lambda_{j}\left(t, x_{t} \mid \theta_{k}^{j}\right)=\frac{1}{1+e^{-h_{\mathrm{j}}\left(t, x_{\mathrm{t}} \mid \theta_{\mathrm{k}}^{\mathrm{j}}\right)}}
$$

where

$$
h_{j}\left(t, x_{t} \mid \theta_{k}^{j}\right)=r_{j}\left(e_{t}, \alpha_{j}\right)+\beta_{j}^{\prime} z_{t}+g_{j}\left(t, \gamma_{j}\right)+\theta_{k}^{j}
$$

Here, $x_{t}^{\prime}=\left(e_{t}, z_{t}^{\prime}\right), r_{j}\left(e_{t}, \alpha_{j}\right)$ denotes a function of remaining entitlement $e_{t}$, the vector $z_{t}$ includes levels of benefits, wages, demographics and time changing demand measures. ${ }^{24}$ Finally, $g_{j}\left(t, \gamma_{j}\right)$ is a function capturing the duration dependence.

To give an example of how the sample likelihood is evaluated in a competing risks specification with layoff and quit hazards, assume away any complications arising from the presence of unobserved heterogeneity. Under the assumption that layoff notes arrive in the morning mail, before quit decisions are contemplated, the unconditional probability of someone leaving employment through

\footnotetext{
${ }^{24}$ In order to streamline notation, we do not use individual $\mathrm{i}$ subscript in any of the formulas.
} 
a layoff at duration $t$ is

$$
L_{e}^{l}(t)=\lambda_{l}\left(t, x_{t}\right) S_{e}(t-1), \text { where } S_{e}(t-1)={ }_{v=1}^{\gamma^{-1}}\left[1-\lambda_{q}\left(v, x_{v}\right)\right]\left[1-\lambda_{l}\left(v, x_{v}\right)\right]
$$

and where $\lambda_{q}$ and $\lambda_{l}$ denote the quit and layoff hazards respectively. $S_{e}(t-1)$ gives the probability of a given spell lasting at least $t-1$ periods. A likelihood contribution of a quit at duration $t$ is defined similarly:

$$
L_{e}^{q}(t)=\lambda_{q}\left(t, x_{t}\right)\left(1-\lambda_{l}\left(t, x_{t}\right)\right) S_{e}(t-1)
$$

For an employment spell which is still in progress at the end of our sampling frame, at time $T$, one enters the employment survival probability $S_{e}(T)$. The sample likelihood then equals the product of individual likelihood contributions.

Next, allow for multiple employment and unemployment spells and introduce unobserved heterogeneity. The primary tool for dealing with unobserved factors is a heterogeneity distribution which uses N-tuples of unobserved factors (McCall 1996), where $\mathrm{N}$ is the number of hazard functions to be estimated. The reemployment and job exit processes create correlation between unobserved characteristics in different types of spells. Thus, the competing risks employment hazards, the overall unemployment hazard and the unobserved heterogeneity distribution are estimated jointly, allowing for a full correlation structure of the unobservables. This general type of heterogeneity is parametrized using the 3-tuple distribution described in Table 2, where $u, l$ and $q$ denote overall unemployment hazard, layoff and quit employment hazards, respectively. $K$ denotes the number of estimated points of support of the mixing distribution.

To see an example of how the likelihood is formed, consider a worker leaving the first unemployment spell after $t$ weeks, then getting laid off after $s-t$ weeks on a job and staying in the second unemployment spell till the date of the interview, say at $T-s$ weeks into the last spell. His likelihood contribution becomes

$$
L^{u, l, u}(t, s, T)={ }_{k=1}^{K} p\left(\Theta_{k}\right) L_{u}\left(t \mid \theta_{k}^{u}\right) L_{e}^{l}\left(s \mid \theta_{k}^{q}, \theta_{k}^{l}\right) S_{u}\left(T \mid \theta_{k}^{u}\right)
$$


where $\Theta_{k} \equiv\left(\theta_{k}^{q}, \theta_{k}^{l}, \theta_{k}^{u}\right), p\left(\Theta_{k}\right)$ is the probability of having the unobserved components $\Theta_{k}$, and

$$
L_{e}^{l}\left(s \mid \theta_{k}^{l}, \theta_{m}^{q}\right)=\lambda_{l}\left(s, x_{t} \mid \theta_{k}^{l}\right)_{v=1}^{\mho^{-1}}\left[1-\lambda_{l}\left(v, x_{v} \mid \theta_{k}^{l}\right)\right]\left[1-\lambda_{q}\left(v, x_{v} \mid \theta_{m}^{q}\right)\right] .
$$

Finally, the unemployment spell likelihood contributions in Equation 5 are defined analogously:

$$
L_{u}\left(t \mid \theta_{k}^{u}\right)=\lambda_{u}\left(t, x_{t} \mid \theta_{k}^{u}\right)_{v=1}^{\gamma^{-1}}\left[1-\lambda_{u}\left(v, x_{v} \mid \theta_{k}^{u}\right)\right] \text { and } S_{u}\left(T \mid \theta_{k}^{u}\right)={ }_{v=s+1}^{Y T}\left[1-\lambda_{u}\left(v, x_{v} \mid \theta_{k}^{u}\right)\right] .
$$

One can compute individual contributions to the sample likelihood for other labor market histories in a similar way. The number of points of support of the distribution of unobservables $\left(N_{\theta}^{u}, N_{\theta}^{q}\right.$ and $N_{\theta}^{l}$ ) is assumed to be finite and is determined from the sample likelihood. Note the assumption of $\theta^{u}, \theta^{q}$ and $\theta^{l}$ staying the same across multiple unemployment and employment spells respectively. Detailed estimation strategy issues are discussed below.

\subsection{Employment Hazard Estimates}

We start by estimating the employment hazard functions with no unobserved heterogeneity. ${ }^{25}$ In terms of the notation introduced in Section 5.1, $\theta_{k}=\theta \forall k$. Table 3 contains the estimates for the competing risks employment hazard functions based on assuming firms and workers do not take eligibility for future UI claims into account. Let us first discuss the layoff hazard estimates. In column (1) we control for the potential UI compensation by including a dummy variable equal to one in each week when a given worker would be entitled for UI in the case of a layoff. We also control for the potential dollar amount of weekly UI benefits. Being entitled to UI compensation significantly raises the layoff hazard. The negative estimate of the potential benefits coefficient contradicts the economic intuition of our model but is not precisely estimated. Higher benefits lead to lower risks of layoff in the adjustment cost models (e.g., Card and Levine, 1992).

\footnotetext{
${ }^{25}$ The employment hazard empirical specifications capture the effect of explanatory variables on the length of an employment spell, which does not correspond to the cummulated job duration (seniority) for recalled workers. Our focus is on the effect of UI on job separations, and not on the issue of seniority. The amount of potential UI compensation -which is computed for each individual at each point in time- is based on the length of employment spells and earnings in the base period and does not depend on the duration of a specific worker-firm employment relationship.
} 
Next, we allow for effects of the length of available entitlement, conditional on the worker being eligible. Specifically, we add a step function in the value of entitlement. The base case are those with more than 52 weeks of available UI compensation. ${ }^{26}$ The table also reports the fraction of weekly observations covered by each of the entitlement steps. Column (2) lists the estimated coefficients which indicate that, conditional on eligibility, the amount of entitlement plays no role in the firm's layoff decisions as the steps in entitlement are neither individually nor jointly significant. ${ }^{27}$ The estimated quit hazard function is presented in Column (3). Being entitled to UI compensation has no effect on the quit probability. UI compensation played no significant role in any of the quit hazards we have estimated.

Part of the entitlement variation comes from various extended benefits programs which trigger on and off at different points in time across states. The actual trigger dates of these programs depend on the level of the state or national insured unemployment rate. Properly controlling for the demand side effects is therefore important for disentangling demand effects from the effect of longer entitlement. To measure demand effects we use the monthly state unemployment rate average and deviation from this state specific mean. We also use the industry specific national monthly unemployment rate. ${ }^{28}$ Controlling for demand conditions was successful in that all of the significantly estimated demand effect coefficients have the expected sign. Higher levels of the state unemployment rate (in deviation from a mean) significantly raise the layoff probability. Averages of the state unemployment rates contain state specific long-term levels of unemployment and could be confounded by other time-invariant state specific effects (there are no state dummies in any of the specifications). This coefficient is not precisely estimated in the layoff hazard, while the variable

\footnotetext{
${ }^{26}$ We have also estimated specifications including a dummy indicating the first week when a worker becomes eligible, but the estimated coefficient never reached conventional levels of statistical significance. This might suggest that in the U.S., unlike in Canada (see Baker and Rea 1993), the agents' ability to precisely impute the timing of eligibility is low. Alternatively, the optimal job duration in the U.S. could be longer than that required for UI eligibility even in firms which are engaged in temporary layoff strategies, perhaps because of lower volatility of demand and consequently lower layoff pressures during periods of low demand. Finally, U.S. firms might be less willing to keep workers they intend to lay off permanently just to ensure their UI coverage.

${ }^{27}$ We have experimented with different choices of the base case and the finding of no significant impact of any of the entitlement steps was robust to the base case choice.

${ }^{28}$ We have also experimented with other demand measures with no impact on the estimates of interest.
} 
significantly reduces the quit hazard. Workers appear to be more cautious about quitting their jobs in regions with persistently high unemployment rates.

We also control for a standard set of demographic regressors including the TAA dummy, which equals to one when the worker can receive TAA compensation in the case of a layoff. The probability of exit from a given state is also allowed to vary with seasonal effects by adding a set of quarterly dummies to each specification. In all hazards we control for the industry class and a set of year dummies. TAA workers are less likely to quit, while the effect on the layoff hazard is not precisely measured conditional on the industry unemployment rate and a set of industry dummies. Workers with higher wages are significantly less likely to exit their jobs in both employment hazards. Highly educated workers are significantly more likely to quit their jobs but are less likely to be laid off. Age plays an important role in both hazards, reducing the likelihood of a quit and affecting the layoff decisions in a nonlinear way where both younger and older workers are at a higher risk of layoff. Being a union member has a large and significant effect on reducing both of the hazards. If the current employment spell is in fact a recall spell, the probability of being laid off is higher, while quits become less likely.

The effect of spell duration on the transition probabilities is specified as a step function in duration, with each step chosen to cover at least $5 \%$ of transitions. ${ }^{29}$ Such flexible parametrization should avoid any influence of the duration dependence specification on estimation of other coefficients. The baseline hazard estimates are available from the author upon request.

Next, unobserved heterogeneity is allowed for in the estimation procedure. Controlling for unobserved person specific characteristics has been important in a number of empirical applications (e.g., Ham and LaLonde, 1996), and we carry out a sensitivity analysis of using different distributional assumptions for the heterogeneity terms. First, we estimate the employment competing risks with a 2-tuple distribution, allowing the unobserved factors in the layoff and quit hazards to be correlated.

\footnotetext{
${ }^{29}$ For a similar approach see Ham and Rea (1987) or Meyer (1990). In the specifications with no unobserved heterogeneity, we also experimented with richer specifications using $2.5 \%$ steps in duration, with no effect on the parameters of interest.
} 
Second, we control for potential selection bias into multiple spells by estimating the employment and unemployment hazards jointly, allowing for a full correlation structure of the unobservables.

Table 4 reports the layoff UI coefficients from the heterogeneity estimation. We have estimated both i) specifications allowing for the amount of entitlement and ii) specifications conditional on only the eligibility dummy. The no-heterogeneity results suggest using the more parsimonious specification. Further, in most specifications, including those accounting for unobservables, the entitlement steps were not jointly significant. Hence, we present the parsimonious estimation here; the results including the step function in entitlement are available upon request. The quit hazard UI coefficients were not significant in any of the specifications and are not reported, as well as the demographic and demand coefficients, which were not affected by introducing heterogeneity except as noted below. Column (1) is taken from Table 3 for comparison. The estimates from the specifications with 2-tuple heterogeneity distribution (quit and layoff) are presented in column (2). Introducing unobserved heterogeneity was strongly supported by the estimated sample likelihood. ${ }^{30}$ Although the UI parameters are not affected by introducing the 2-tuple heterogeneity, both the recall and union dummy estimates in the layoff hazard increase by more than four times the size of their standard errors. None of the quit hazard coefficients was sensitive to unobserved factors.

Column (3) contains the estimates from a specification where sample selection is controlled. The employment durations are estimated jointly with the overall unemployment hazard using the 3 -tuples heterogeneity distribution from Table 2 with two points of support (i.e. $K=2$ ). The positive layoff effect of being eligible increases slightly, but correcting for selection bias was not very important as none of the coefficients moved by more than the size of their standard errors.

When searching for additional (more than 2) points of support for 3-tuple heterogeneity, the likelihood was unbounded in large negative values of one of the heterogeneity terms in the quit hazard. This suggested estimation of a defective risk model, with a heterogeneity distribution parametrizing

\footnotetext{
${ }^{30}$ Log-likelihood improved by 47.2 when going from no heterogeneity to 2 points of support for 2 -tuples when there were 3 more coefficients to be estimated. To make this comparison to the joint log-likelihood of quits and layoffs from colum (2), one has to sum up the quit and layoff no-heterogeneity log-likelihoods, which were estimated separately.
} 
the probability of never leaving employment through a quit. Further motivation for this type of estimation comes from the empirical hazard literature, which argues that for processes in which the probability of exit is very low, one should reflect this fact in the estimation by parametrizing the probability of never leaving a given state. ${ }^{31}$ Heckman and Walker (1990) use the general framework developed in Heckman and Singer (1984) to allow for defective risks in the context of unobserved heterogeneity in a continuous time, single exit model. Here, a similar approach is applied to discrete time estimation with multiple exits.

There is a natural way of incorporating defective risk probabilities into the N-tuple heterogeneity distribution. In doing so one retains the richness of the estimated heterogeneity distribution while adding a new dimension to it. The empirical strategy used here is to estimate as many points of support for the usual N-tuple heterogeneity as possible and then substitute a fixed large negative value for those unobserved factors which pointed in the direction of the defective risk in the previous estimation. This large negative $\theta=-M$ is not to be estimated, and only the probability of having this unobserved factor, i.e. of never leaving a given state, enters the maximization problem. ${ }^{32}$ All other explanatory variables are excluded from the hazard with the defective $\theta$. This strategy incorporates the traditional defective risk (absorption state, stayer) model into a competing risk setting with unobserved heterogeneity.

We estimate the defective-risk (stayer) probability for the quit hazard and allow for two different corresponding points of support for the heterogeneity pair of $\theta^{l}$ and $\theta^{u}$. Simultaneously, we allow for two points of support for the full, non-defective heterogeneity $\left(\theta^{l}, \theta^{q}, \theta^{u}\right) .{ }^{33}$ There are four probabilities to be estimated (which requires only three parameters). Equation 5 is used with for the non-defective heterogeneity. For the case of defective quit risk, the likelihood contribution in

\footnotetext{
${ }^{31}$ For example, Schmidt and Witte (1989) look at the probability of returning to prison for a sample of formerly arrested individuals. They parametrize both the probability of eventual return and the timing of return.

${ }^{32}$ We use $M=100$ in the estimation, which sets the (quit) hazard at $10^{-43}$.

${ }^{33}$ Searching for additional points of support for this most general heterogeneity distribution resulted in trivial increases of the log-likelihood.
} 
case of a layoff would be

$$
L_{e}^{l}\left(t \mid \theta^{q}=-M, \theta_{3}^{l}\right)=\lambda_{l}\left(t, x_{t} \mid \theta_{3}^{l}\right){ }_{v=1}^{\psi-1}\left[1-\lambda_{l}\left(v, x_{v} \mid \theta_{3}^{l}\right)\right],
$$

and it would equal zero if the transition were a quit.

The results allowing for defective risks heterogeneity are presented in column (4) of Table 4. The estimated likelihood function improves upon the maximized value of the model with no defectiverisk heterogeneity. The estimate of the eligibility dummy increases by approximately the size of its standard error when compared to the joint specification in column (3). The positive eligibility coefficient is now almost twice as large as the no-heterogeneity estimate in column (1), although still within two standard deviations. Except for the increase in the potential benefits coefficient, the other estimates were almost identical to those from the more conventional models. The estimated probability of never leaving employment through a quit is 0.08 (with a corresponding standard deviation of 0.021).

The specifications based on allowing workers and firms to account for the possibility of future multiple UI claims are presented in Table 5. The reported means of the entitlement and eligibility dummies show that the imputation procedure now makes more workers eligible and increases the average amount of available entitlement. When we control for the effect of UI eligibility and benefits on employment durations, the estimates in columns (1) and (3) are not affected by the different assumptions regarding future claims. Being entitled to UI compensation makes quits less likely, but the effect is not precisely estimated. Column (2) lists estimates which control for the length of available UI entitlement. Compared to Table 3, accounting for future claims affects the parameters of interest as the eligibility dummy coefficient is now relatively small and insignificant. ${ }^{34}$ When controlling for unobserved heterogeneity we again estimate both specifications with and without the step function in entitlement. The entitlement steps are not jointly significant at the $5 \%$ level

\footnotetext{
${ }^{34}$ Further, given that we control for eligibility, having 14 to 26 weeks of available entitlement significantly raises the layoff hazard. The joint likelihood ratio test for the four entitlement steps, however, does not reach conventional levels of statistical significance.
} 
in six out of the total of eight estimated layoff hazards (four for each assumption about agents' ability to impute eligibility for future UI spells). Moreover, most of the estimated UI coefficients in these richer specifications are imprecisely estimated, and we conclude that the data does not allow separate identification of both the eligibility and entitlement effects. We proceed with the more parsimonious parametrization.

Introducing unobserved heterogeneity in columns (2) to (4) of Table 6 quantitatively affects the eligibility coefficient. When we estimate the two employment hazards jointly, allowing for a 2-tuple correlated heterogeneity distribution, the coefficient becomes smaller and insignificant. Controlling for the effects of sample selection in column (3), however, raises the estimated eligibility effect by more than one standard error size and the defective risk (stayer) heterogeneity estimation in column (4) confirms the large significant positive effect of UI eligibility on layoffs. ${ }^{35}$ The behavior of all remaining coefficients was similar to the estimation based on not accounting for future UI claims.

\subsection{Unemployment Hazard Estimates}

The specifications in columns (3) and (4) of Tables 4 and 6 involve also estimating the overall unemployment hazard. None of the unemployment hazard coefficients was sensitive to introducing the heterogeneity factors. Only the set of coefficients with no unobserved heterogeneity is therefore reported in Table 7. Large values of entitlement and higher UI benefits make unemployed workers less likely to leave unemployment. Such findings are in accord with both job search models and empirical unemployment duration literature. Finally, the unemployment hazard was not materially affected by the type of assumption regarding future UI claims. ${ }^{36}$

\footnotetext{
${ }^{35}$ The defective-risk heterogeneity estimation with entitlement steps also confirms the large positive effect of eligibility from the more parsimonious specification of column (4).

${ }^{36}$ Note that most of the unemployment data comes from the initial unemployment spells. Since the data set does not include information on the employment histories preceding the initial spell of unemployment, we can only control for the possibility of multiple UI claims in the second and third spell of unemployment. The extent to which the value of entitlement is affected by the future claim assumption in the unemployment hazards is, therefore, much smaller than with the employment hazards, where we have enough information to impute future UI claims even in the first employment spells.
} 


\subsection{Simulations}

To translate hazard function coefficient estimates into a meaningful magnitude, researchers typically use the estimated functions to compute the expected duration of a given state under different values of the explanatory variable of interest. Such an exercise then provides a measure of elasticity of duration of a given state with respect to the explanatory factor, e.g. UIC. For example, the expected duration of unemployment (based on a sample of single spells of unemployment) can be computed as

$$
E_{u}(t \mid X)=I^{-1}{ }_{i=1 t=1}^{X^{I}} t L_{u}\left(t \mid x_{i t}\right)
$$

where $L_{u}\left(t \mid x_{i t}\right)$ denotes the unconditional probability of leaving unemployment at duration $t,{ }^{37}$ and where $I$ is the number of spells in a sample, $x_{i t}$ is the vector of all explanatory variables for a spell $i$ at duration $t$ (including measures of UIC), and $X$ denotes the collection of all $x_{i t}$ vectors.

With multiple-spell, multiple-state data, the analysis of single-state expected duration does not result in a complete evaluation of a given effect since ideally one would like to know about the effects of a given explanatory variable on both duration and occurrence of spells. As illustrated in the introductory section, ignoring the effect of UIC on employment duration and focusing solely on its effect on unemployment duration may result in underestimation of the UIC effect on time spent in employment. We therefore provide a complete (short-run) measure of the overall effect of UIC on labor market histories by considering the proportion of time spent employed within the sample frame and how it changes in response to changes in the UIC parameters.

In particular, we simulate the processes of finding and losing work, starting with an initial spell of unemployment and spanning the sample frame for each individual in the data. These simulations are used to predict effects of a policy change on the group of displaced workers who comprise the analyzed data set. We use the estimated hazard functions and the personal characteristics of individuals at the beginning of the sample frame to evaluate the hazard out of a given state at each

\footnotetext{
${ }^{37}$ See Equation 7 for a definition of $L_{u}\left(t \mid x_{i t}\right)$ in the presence of unobservables.
} 
point in time, properly adjusting for time-changing covariates such as duration and remaining UI entitlement. Each calculated hazard value is then compared to a random draw from a uniform distribution. Whenever the hazard exceeds the draw, one simulates a transition into another state and starts evaluating the hazards out of the new state, conditional on the individual's past labor market history. ${ }^{38}$ Each worker's weekly labor market history during the sample frame of approximately 3.5 years is simulated 100 times. A final complication arises in the presence of unobservables. Here, we again use random draws from the uniform distribution to determine each individual's 'type' $\left(\Theta_{k}\right)$ by comparing the random draw with the probability distribution of the heterogeneity terms. This assignment of 'type' occurs before each of the 100 simulations per person is conducted.

Table 8 presents the results of these simulations. First, we test to what extent the estimated model can approximate the data using the information from the first week of the first unemployment spell and the UI eligibility rules, which are the only input into the simulations. ${ }^{39}$ Second, we measure the size of the UIC eligibility effect in the employment hazard and we evaluate the effect of changes in the UIC entitlement. All three exercises are based on estimates accounting for future UIC claims and are performed twice: first based on specifications with no unobservables and second using the joint heterogeneity model (see the Table for details).

The first panel of Table 8 shows that both the no-heterogeneity specification and the estimated model allowing for unobservables are able to closely mimic important features of the actual labor market histories. While both specifications do a fine job predicting the expected durations of each type of spells, the simulation based on the heterogeneity model also accurately mimics the fraction of quits on all employment terminations.

Next, we measure the size of the UIC eligibility coefficient in the employment hazard. Setting this coefficient to zero results in simulated employment durations that are on average 3.5 to 11.3

\footnotetext{
${ }^{38}$ For example, when evaluating the unemployment hazard, the value of UIC depends on whether the worker quit his previous job or was laid off.

${ }^{39}$ The simulations are simplified in that they do not adjust the time-changing demand conditions according to calendar time.
} 
weeks longer and increases the fraction of time spent employed within the sample frame by 0.7 to 2.7 percentage points. ${ }^{40}$

The third panel of Table 8 considers the effect of lowering the maximum UIC entitlement from 39 to 26 weeks for all workers in the sample. ${ }^{41}$ Such policy corresponds to suspending one of the extended benefits program (see Section 4) and appears to lead to unemployment spells shorter by 2.4 to 2.8 weeks on average. Consequently, the fraction of time at work increases by 2 to 2.2 percentage points. Hence, it appears that the change in fraction of time spent in employment resulting from suspending an extended benefits program is comparable in magnitude (but opposite in sign) to the change induced by the heterogeneity-based estimate of the UIC effect on employment durations.

\section{Conclusion}

Empirical evidence on the effect of UI coverage on employment durations is scarce. This gap in the literature is a potential source of underestimation of the total impact of UIC on labor market histories. We employ methods similar to those used in the unemployment duration literature to examine how the UI system affects duration of employment. Unemployment and employment spells are analyzed jointly in order to control for selection into multiple spells. This also allows for assessing the UIC effect on the fraction of time spent in employment.

The empirical results suggest that eligibility for UI compensation significantly raises the probability of a layoff. Conditional on eligibility, however, neither the length nor the dollar amount of the UI compensation to which workers are entitled appear to affect the risks of layoff. No aspect of UI affects the probability of a quit in any of the estimated specifications.

Further, we find a relatively small effect of sample selection. This finding is reassuring for empirical applications which use multiple spell unemployment data to estimate the effect of the UI system on outflow from unemployment (e.g., Ham and Rea, 1987). Our most general heterogeneity

\footnotetext{
${ }^{40}$ There is also a residual effect on unemployment durations resulting from simulating a finite calendar time period. Also note that all reported average durations are not corrected for censoring at the end of the sampling frame.

${ }^{41}$ We ignore the data on the initial entitlement in the first unemployment spell and set initial entitlement to 39 or 26 for all workers in all unemployment spells, as long as they are entitled to UIC.
} 
specification also allows for the possibility of defective risks, an important consideration when the probability of a particular type of exit is very low for a fraction of the sample, as is the case with quits in the current study. Finally, the sensitivity analysis focuses on how different assumptions about the ability of firms and workers to impute available UI compensation affect the estimation.

Our theoretical model predicts that the layoff probability should increase with the length of available UI entitlement. While the empirical results confirm that entitlement eligibility is positively related to the layoff risks, we do not find important effects of the length of UI entitlement on layoffs conditional upon being eligible. This inconsistency with the theoretical model might be due to (i) agents' inability to correctly impute the level of available UI entitlement, in which case they could base their decisions on the simpler criterion of eligibility; and (ii) an imprecise modelling of the structure of the layoff costs.

Moreover, our results conflict with those of Anderson and Meyer (1994), who use quarterly data to estimate the probability of a layoff as a function of the firm's experience rating and the available UI compensation. They find a significantly positive effect of UI benefits, but a negative or insignificant entitlement effect. Their results are, however, very sensitive to dealing with the person-specific unobservables. This study differs from Anderson and Meyer (1994) in that it uses event-history models on weekly data, and thus controls for duration dependence, monthly changes in demand, and sample selection in a coherent statistical framework. ${ }^{42}$

Both the conflicting theoretical and empirical results call for further analysis of the layoff impact of UI. Such research should focus on the agents' forecasting abilities as well as on the structure of the layoff costs, and ideally use large and more representative data sets. ${ }^{43}$

\footnotetext{
${ }^{42}$ Their work has an advantage in that, while they cannot employ such models, they are able to use an extremely large representative data set over a longer time period, albeit at the cost of using a linear probability model to reduce computation costs. Further, they drop the observations in which the worker would not qualify for UI benefits, while we include such weeks and spells. They use the worker's base period earnings and high quarter earnings together with the state UI formulas to determine UI eligibility and amount were the worker to separate in a given quarter. In contrast, the present study follows workers over time to account also for their labor market histories and for the extended benefit program triggers, which also affect the amount of available UI compensation.

${ }^{43}$ The advantage of analyzing displaced workers, as in this paper, is that the focus is on individuals who experience more 'treatment' of UIC.
} 
The simulation evidence presented in this paper points to the importance of capturing the UIC effect on both duration and occurrence of spells. If we consider the fraction of time spent employed as the proper measure of the UIC effects, the simulations suggest that the UIC eligibility effect of shortening employment durations is roughly comparable in size (but opposite in sign) to the effect of suspending (triggering off) an extended benefits program for all workers in the sample on shortening unemployment durations. 
Curtis Eberwein, Hidehiko Ichimura, and Randall Filer for their help and valuable suggestions. Thanks go also to John Engberg for generously providing the raw data and for his helpful comments.

\section{Bibliography}

Anderson, P.M. and B.D. Meyer, 1994, The Effects of Unemployment Insurance Taxes and Benefits on Layoffs Using Firm and Individual Data, NBER Working Paper No. 4960.

Baily, M.N., 1977, On the Theory of Layoffs and Unemployment, Econometrica 45, 1043-1063.

Baker, M. and S.A. Rea, 1998, Employment Spells and Unemployment Insurance Eligibility Requirements, Review of Economics and Statistics 80, 80-94.

Burdett, K., 1978, A Theory of Employee Job Search and Quit Rates, American Economic Review 68, 212-220.

Burdett, K., and B. Hool, 1983, Layoffs, Wages and Unemployment Insurance, Journal of Public Economics 21, 325-327.

Card, D. and P.B. Levine, 1992, Unemployment Insurance Taxes and the Cyclical and Seasonal Properties of Unemployment, Journal of Public Economics 53, 1-29.

Christofides, L.N. and C.J. McKenna, 1996, Unemployment Insurance and Job Duration in Canada, Journal of Labor-Economics 14, 286-312.

Corson, W. and W. Nicholson, 1981, Trade Adjustment Assistance for Workers: Results of a Survey of Recipients under the Trade Act of 1974, Research in Labor Economics 4, 417-469.

Devine, J. and N. Kiefer, 1991, Empirical Labor Economics (Oxford, Oxford University Press). Feldstein, M.S., 1976, Temporary Layoffs in the Theory of Unemployment, Journal of Political Economy 84, 837-857.

Haltiwanger, J., 1984, The Distinguishing Characteristics of Temporary and Permanent Layoffs, Journal of Labor Economics 2, 523-538.

Ham, J. and R. LaLonde, 1996, The Effect of Sample Selection and Initial Conditions in Duration Models: Evidence From Experimental Data on Training, Econometrica 64, 175-207.

Ham, J. and S.A. Rea, 1987, Unemployment Insurance and Male Unemployment Duration in 
Canada, Journal of Labor Economics 5, 325-353.

Heckman, J.J. and B. Singer, 1984, A Method of Minimizing the Impact of Distributional Assumptions in Econometric Models for Duration Data, Econometrica 52, 271-320.

Heckman, J.J. and J.R. Walker, 1990, The Relationship between Wages and Income and the Timing and Spacing of Births: Evidence from Swedish Longitudinal Data, Econometrica 58, 14111441.

Jovanovic, B., 1979, Firm-specific Capital and Turnover, Journal of Political Economy 87, 12461260.

Jurajda, S., 1997, An Empirical Evaluation of the Effects of the U.S. Unemployment Insurance System on Employment and Unemployment, dissertation, University of Pittsburgh.

Jurajda, S., 2000, Unemployment Insurance and the Timing of Layoffs, CERGE-EI Discussion Paper No. 46, Charles University, Prague.

Katz, L. and B. Meyer, 1990, Unemployment Insurance, Recall Expectations, and Unemployment Outcomes, Quarterly Journal of Economics 105, 973-1002.

Meyer, B., 1990, Unemployment Insurance and Unemployment Spells, Econometrica 58, 757782.

McCall, B.P., 1996, Unemployment Insurance Rules, Joblessness, and Part- time Work, Econometrica 64, 647-682 .

Mortensen, D.T., 1977, Unemployment Insurance and Job Search Decisions, Industrial and Labor Relations Review 30, 505-517.

Rogers, C.L., 1998, Expectations of Unemployment Insurance and Unemployment Duration, Journal of Labor Economics 16, 630-666.

Schmidt, P. and A.D. Witte, 1989, Predicting Criminal Recidivism Using 'Split Population' Survival Time Models, Journal of Econometrics 40, 141-159.

Topel, R.H., 1983, On Layoffs and Unemployment Insurance, American Economic Review 73, $541-559$ 


\section{Appendix: Kaplan-Meier Empirical Hazards}

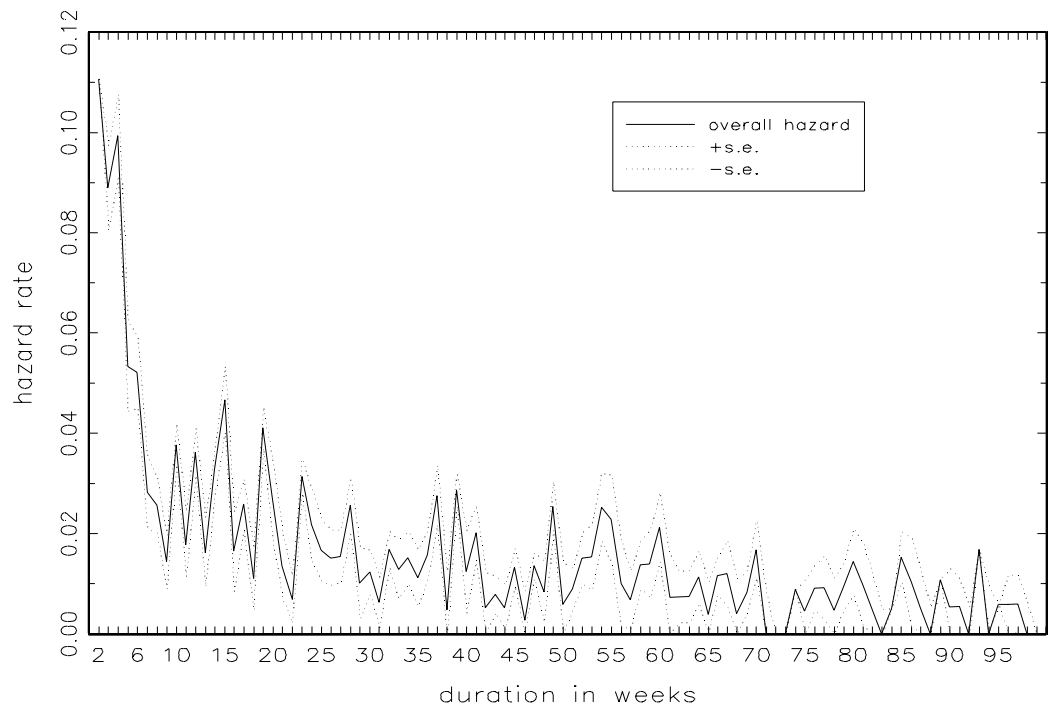

Figure .1: Overall Empirical Hazard for Unemployment Spells 


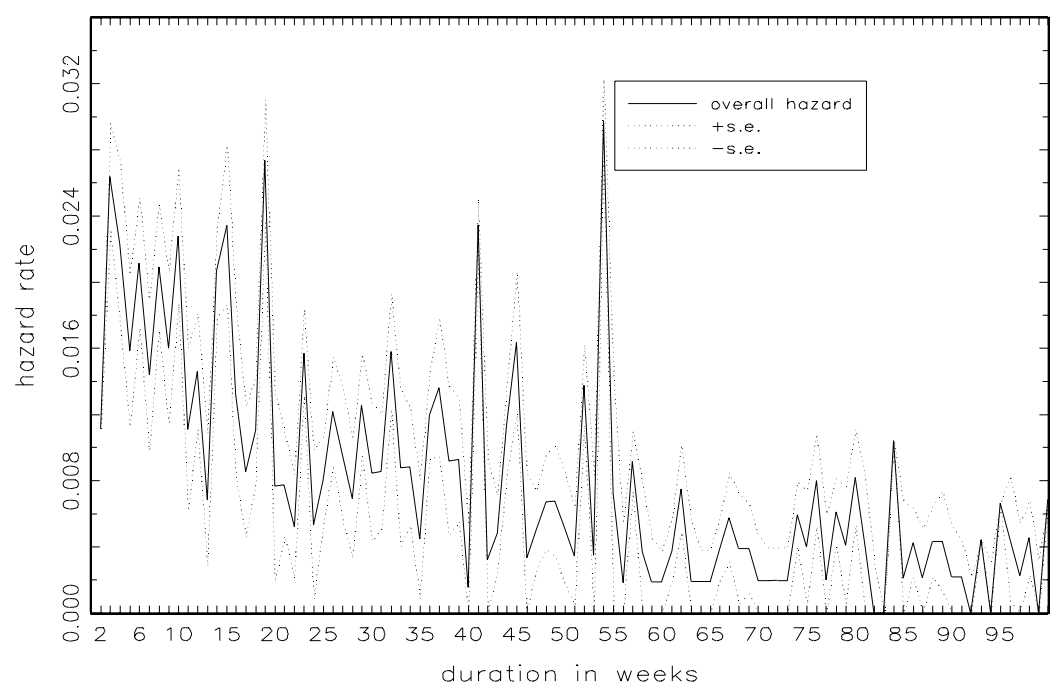

Figure .2: Empirical Hazards for Employment Spells: Overall Hazard

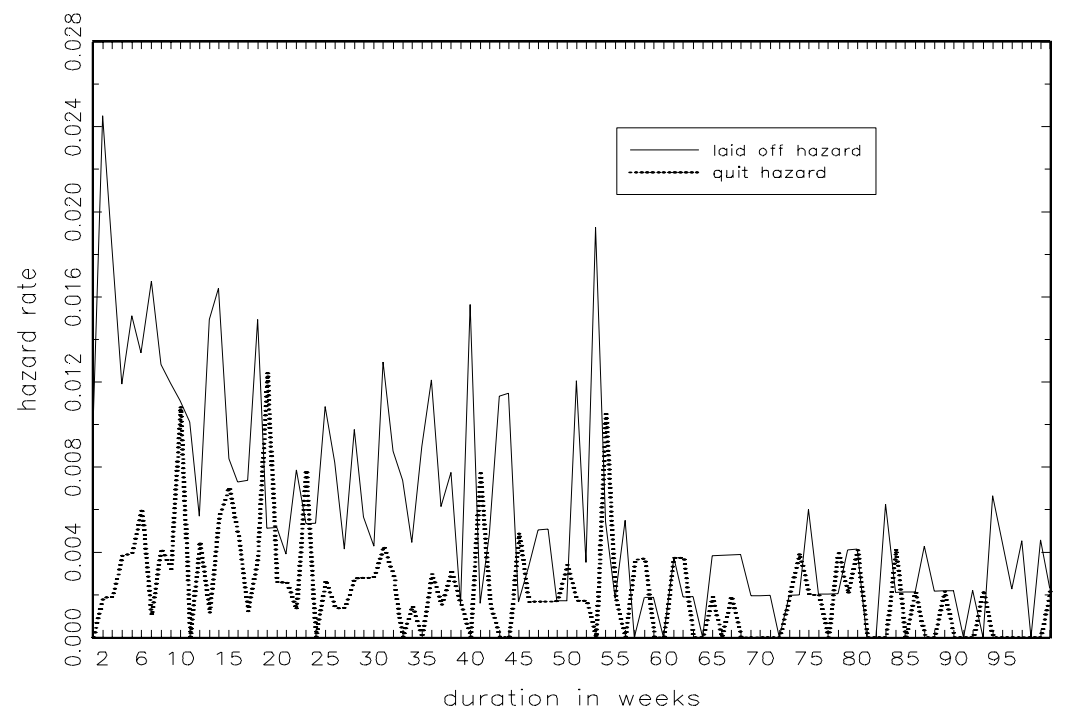

Figure .3: Empirical Hazards for Employment Spells: Competing Risks 


\section{Main Tables}

Table 1: Individual and Spell Characteristics

Unemployment Spells

Number of Individuals $=808$ Number of Spells $=1375$

\begin{tabular}{||lll|ll||}
\hline Variable & Mean & Std.Dev. & Dummy Variable & Mean \\
\hline Education & 11.4 & $(2.45)$ & Union & 0.52 \\
Age & 34.6 & $(12.0)$ & Previous Recall & 0.46 \\
Previous Wage & 242. & $(105)$. & UI Non-recipient & 0.15 \\
UI Entitlement $($ if $>0)$ & 52.5 & $(13.8)$ & & \\
UI Benefits $($ if $>0)$ & 113. & $(34.3)$ & & \\
Duration & 34.9 & $(46.3)$ & & \\
\hline
\end{tabular}

Employment Spells

\begin{tabular}{||lcc|ll||}
\multicolumn{6}{c|}{ Number of Individuals $=808$} & Number of Spells $=1074$ \\
Wage & 251. & $(116)$. & Recall & 0.61 \\
Potential Entitlement & 22.2 & $(23.9)$ & Quit & 0.25 \\
Potential UI Benefits & 62.3 & $(61.4)$ & & \\
Duration & 85.1 & $(72.3)$ & & \\
\hline
\end{tabular}

(Duration and entitlement are in weeks; all wages and benefits are weekly measures in 1975 dollars.)

Table 2: Heterogeneity Distribution with 3-tuples

$$
\begin{array}{|l|c|}
\hline p\left(\Theta_{1}\right) & \Theta_{1}=\left\{\theta_{1}^{u}, \theta_{1}^{l}, \theta_{1}^{q}\right\} \\
p\left(\Theta_{2}\right) & \Theta_{2}=\left\{\theta_{2}^{u}, \theta_{2}^{l}, \theta_{2}^{q}\right\} \\
\cdots & \cdots \\
p\left(\Theta_{K}\right) & \Theta_{K}=\left\{\theta_{K}^{u}, \theta_{K}^{l}, \theta_{K}^{q}\right\} \\
\hline
\end{array}
$$


Table 3: Employment Hazard Estimates Not Accounting for Future UI Claims

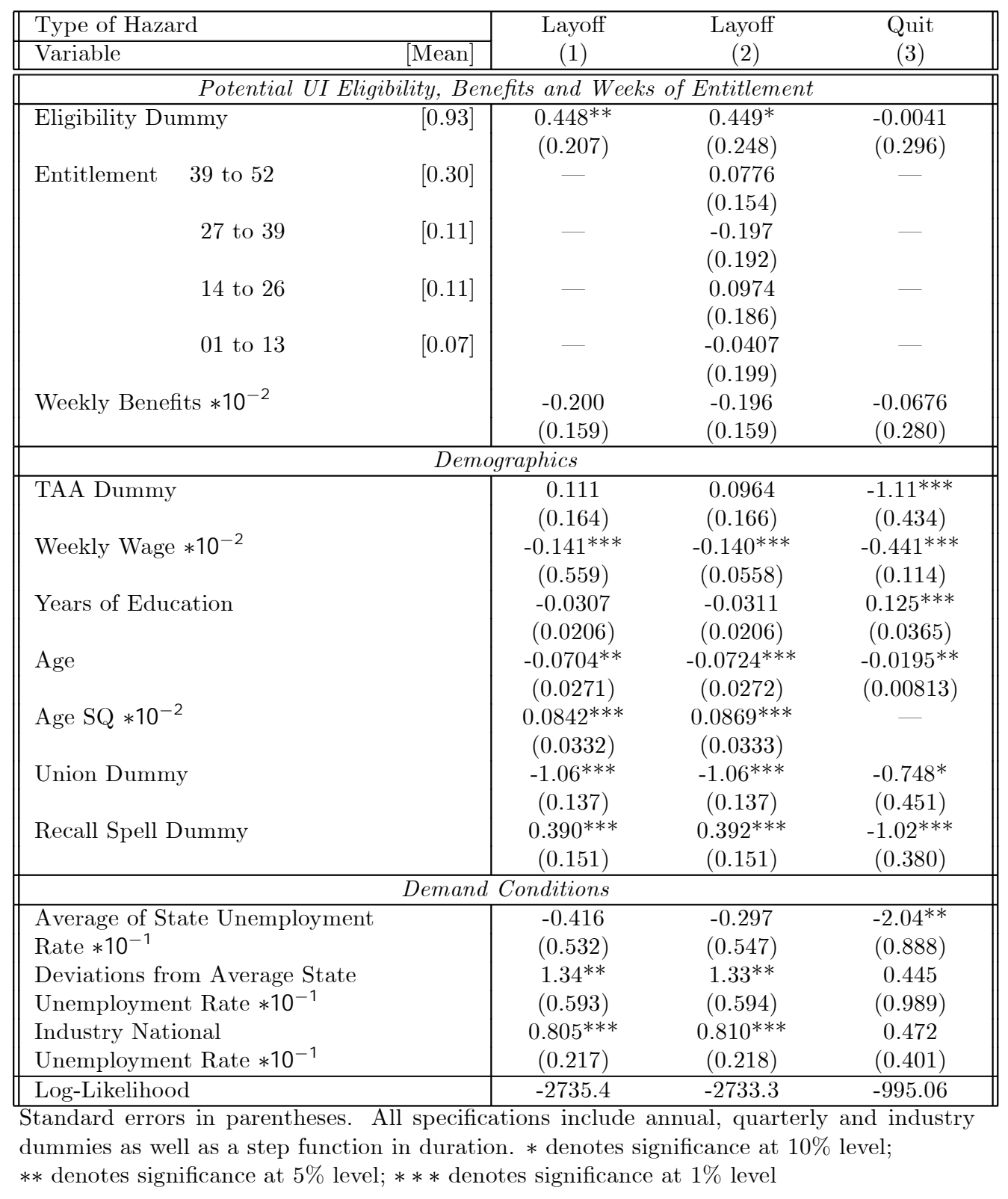


Table 4: Employment Hazard Estimates with Unobserved Heterogeneity not Accounting for Future Claims

\begin{tabular}{||l|cccc||}
\hline Heterogeneity & No & 2-tuple & Joint & Joint/Stayer \\
\cline { 1 - 1 } Variable & $(1)$ & $(2)$ & $(3)$ & $(4)$ \\
\hline \hline Eligibility Dummy & $0.448^{* *}$ & $0.483^{*}$ & $0.534^{*}$ & $0.844^{* * *}$ \\
& $(0.207)$ & $(0.277)$ & $(0.290)$ & $(0.278)$ \\
Weekly Benefits $* 10^{-2}$ & -0.200 & -0.248 & -0.276 & $-0.412^{*}$ \\
& $(0.159)$ & $(0.210)$ & $(0.219)$ & $(0.222)$ \\
\hline Log-Likelihood & -2735.4 & -3683.3 & -8173.8 & -8131.7 \\
\hline
\end{tabular}

Standard errors in parentheses. For a standard set of regressors see Table 3 . 
Table 5: Employment Hazard Estimates Accounting for Future UI Claims

\begin{tabular}{|c|c|c|c|c|c|}
\hline \multicolumn{3}{|c|}{ Type of Hazard } & \multirow{2}{*}{$\begin{array}{l}\text { Layoff } \\
(1) \\
\end{array}$} & \multirow{2}{*}{$\begin{array}{c}\text { Layoff } \\
(2) \\
\end{array}$} & \multirow{2}{*}{$\begin{array}{l}\text { Quit } \\
(3)\end{array}$} \\
\hline Variable & & [Mean] & & & \\
\hline \multicolumn{6}{|c|}{ Potential UI Eligibility, Benefits and Weeks of Entitlement } \\
\hline Eligibility D & mmy & {$[0.95]$} & $\begin{array}{l}0.452^{* *} \\
(0.225)\end{array}$ & $\begin{array}{c}0.299 \\
(0.255)\end{array}$ & $\begin{array}{l}-0.280 \\
(0.308)\end{array}$ \\
\hline Entitlement & 39 to 52 & {$[0.34]$} & - & $\begin{array}{c}0.151 \\
(0.133)\end{array}$ & - \\
\hline & 27 to 39 & {$[0.12]$} & - & $\begin{array}{c}0.115 \\
(0.160)\end{array}$ & - \\
\hline & 14 to 26 & {$[0.06]$} & - & $\begin{array}{c}0.460^{* *} \\
(0.191)\end{array}$ & - \\
\hline & 01 to 13 & {$[0.01]$} & - & $\begin{array}{c}-0.242 \\
(0.340)\end{array}$ & - \\
\hline Weekly Ben & its $* 10^{-2}$ & & $\begin{array}{l}-0.196 \\
(0.160) \\
\end{array}$ & $\begin{array}{l}-0.193 \\
(0.159) \\
\end{array}$ & $\begin{array}{c}0.187 \\
(0.276) \\
\end{array}$ \\
\hline \multicolumn{6}{|c|}{ Demographics } \\
\hline TAA Dumm & & & $\begin{array}{c}0.109 \\
(0.164)\end{array}$ & $\begin{array}{c}0.180 \\
(0.171)\end{array}$ & $\begin{array}{c}-1.178^{* *} \\
(0.434)\end{array}$ \\
\hline Weekly Wag & $* 10^{-2}$ & & $\begin{array}{c}-0.142^{* * *} \\
(0.563)\end{array}$ & $\begin{array}{c}-0.143^{* * *} \\
(0.0562)\end{array}$ & $\begin{array}{c}-0.482^{* * *} \\
(0.115)\end{array}$ \\
\hline Years of Edr & ation & & $\begin{array}{l}-0.0310 \\
(0.0206)\end{array}$ & $\begin{array}{l}-0.0316 \\
(0.0206)\end{array}$ & $\begin{array}{c}0.122^{* * *} \\
(0.366)\end{array}$ \\
\hline Age & & & $\begin{array}{c}-0.0713^{* * *} \\
(0.0271)\end{array}$ & $\begin{array}{c}-0.0715^{* * *} \\
(0.0272)\end{array}$ & $\begin{array}{c}-0.0208^{* * *} \\
(0.0815)\end{array}$ \\
\hline Age $\mathrm{SQ} * 10$ & & & $\begin{array}{c}0.0851^{* * *} \\
(0.0332)\end{array}$ & $\begin{array}{c}0.0861^{* * * *} \\
(0.0333)\end{array}$ & - \\
\hline Union Dumı & & & $\begin{array}{c}-1.06^{* * *} \\
(0.137)\end{array}$ & $\begin{array}{c}-1.06^{* *} \\
(0.137)\end{array}$ & $\begin{array}{c}-0.752^{*} \\
(0.451)\end{array}$ \\
\hline Recall Spell & ummy & & $\begin{array}{c}0.386^{* * *} \\
(0.151) \\
\end{array}$ & $\begin{array}{c}0.368 * * \\
(0.152) \\
\end{array}$ & $\begin{array}{c}-1.01^{* * *} \\
(0.381) \\
\end{array}$ \\
\hline \multicolumn{6}{|c|}{ Demand Conditions } \\
\hline Average of $\mathrm{S}$ & ate Unemployment & & -0.378 & -0.144 & $-1.91^{*}$ \\
\hline Rate $* 10^{-1}$ & & & $(0.531)$ & $(0.549)$ & $(0.885)$ \\
\hline Deviations $\mathrm{f}$ & m Average State & & $1.33^{* *}$ & $1.29^{* *}$ & 0.373 \\
\hline Unemploym & at Rate $* 10^{-1}$ & & $(0.593)$ & $(0.593)$ & $(0.989)$ \\
\hline Industry $\mathrm{Na}$ & onal & & $0.802^{* * *}$ & $0.794^{* * *}$ & 0.472 \\
\hline Unemploym & at Rate $* 10^{-1}$ & & $(0.218)$ & $(0.217)$ & $(0.402)$ \\
\hline Log-Likeliho & & & -2735.8 & -2731.8 & -994.68 \\
\hline
\end{tabular}


Table 6: Employment Hazard Estimates with Unobserved Heterogeneity Accounting for Future Claims

\begin{tabular}{|c|c|c|c|c|}
\hline $\begin{array}{l}\text { Heterogeneity } \\
\text { Variable }\end{array}$ & $\begin{array}{l}\text { No } \\
(1)\end{array}$ & $\begin{array}{l}\text { 2-tuple } \\
(2)\end{array}$ & $\begin{array}{c}\text { Joint } \\
(3)\end{array}$ & $\begin{array}{c}\text { Joint/Stayer } \\
(4)\end{array}$ \\
\hline Eligibility Dummy & $0.452^{* *}$ & 0.382 & $0.787^{* * *}$ & $0.817^{* * *}$ \\
\hline & $(0.225)$ & $(0.273)$ & $(0.275)$ & $(0.291)$ \\
\hline Weekly Benefits $* 10^{-2}$ & -0.196 & -0.111 & -0.166 & -0.278 \\
\hline & $(0.160)$ & $(0.197)$ & $(0.198)$ & $(0.211)$ \\
\hline Log-Likelihood & -2735.8 & -3683.7 & -8177.6 & -8129.3 \\
\hline
\end{tabular}

Standard errors in parentheses. For a standard set of regressors see Table 5 . 
Table 7: Unemployment Hazard Estimates with No Unobserved Heterogeneity

\begin{tabular}{|c|c|c|c|c|}
\hline Accounting for Future Claims & & No & [Mean] & Yes \\
\hline Variable & [Mean] & & 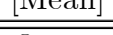 & \\
\hline \multicolumn{5}{|c|}{ Weeks of Remaining UI Entitlement and UI Benefits } \\
\hline Entitlement over 52 & {$[0.08]$} & $\begin{array}{c}-0.585^{* *} \\
(0.222)\end{array}$ & {$[0.09]$} & $\begin{array}{c}-0.671^{* * *} \\
(0.224)\end{array}$ \\
\hline 39 to 52 & {$[0.11]$} & $\begin{array}{l}-0.346^{*} \\
(0.210)\end{array}$ & {$[0.12]$} & $\begin{array}{c}-0.404^{*} \\
(0.213)\end{array}$ \\
\hline 27 to 39 & {$[0.12]$} & $\begin{array}{c}-0.666^{* * *} \\
(0.219)\end{array}$ & {$[0.12]$} & $\begin{array}{c}-0.751^{* * *} \\
(0.221)\end{array}$ \\
\hline 14 to 26 & {$[0.11]$} & $\begin{array}{c}-0.676^{* * *} \\
(0.220)\end{array}$ & {$[0.11]$} & $\begin{array}{c}-0.706^{* * *} \\
(0.223)\end{array}$ \\
\hline 01 to 13 & {$[0.09]$} & $\begin{array}{l}-0.215 \\
(0.216)\end{array}$ & {$[0.08]$} & $\begin{array}{l}-0.0915 \\
(0.218)\end{array}$ \\
\hline No Eligibility Dummy & {$[0.25]$} & $\begin{array}{c}-0.816^{* * *} \\
(0.162)\end{array}$ & {$[0.23]$} & $\begin{array}{c}-0.847^{* * *} \\
(0.165)\end{array}$ \\
\hline Weekly Benefits $* 10^{-2}$ & & $\begin{array}{r}-0.0576 \\
(0.131)\end{array}$ & & $\begin{array}{r}-0.0510 \\
(0.131)\end{array}$ \\
\hline \multicolumn{5}{|c|}{ Demographics } \\
\hline TAA Dummy & & $\begin{array}{c}0.107 \\
(0.110)\end{array}$ & & $\begin{array}{c}0.109 \\
(0.110)\end{array}$ \\
\hline Weekly Wage $* 10^{-2}$ & & $\begin{array}{c}0.0519 \\
(0.0354)\end{array}$ & & $\begin{array}{c}0.0513 \\
(0.0355)\end{array}$ \\
\hline Years of Education & & $\begin{array}{l}-0.0208 \\
(0.0139)\end{array}$ & & $\begin{array}{l}-0.0205 \\
(0.0139)\end{array}$ \\
\hline Age & & $\begin{array}{c}0.0176 \\
(0.0182)\end{array}$ & & $\begin{array}{c}0.0171 \\
(0.0182)\end{array}$ \\
\hline Age $\mathrm{SQ} * 10^{-2}$ & & $\begin{array}{l}-0.0199 \\
(0.0228)\end{array}$ & & $\begin{array}{l}-0.0191 \\
(0.0228)\end{array}$ \\
\hline Previously Recalled Dummy & & $\begin{array}{c}-0.369^{* * *} \\
(0.0721)\end{array}$ & & $\begin{array}{c}-0.365^{* * *} \\
(0.0721) \\
\end{array}$ \\
\hline \multicolumn{5}{|c|}{ Demand Conditions } \\
\hline $\begin{array}{l}\text { Average of State Unemployment } \\
* 10^{-1}\end{array}$ & & $\begin{array}{c}0.375 \\
(0.407)\end{array}$ & & $\begin{array}{c}0.434 \\
(0.408)\end{array}$ \\
\hline $\begin{array}{l}\text { Deviations from Average State } \\
* 10^{-1}\end{array}$ & & $\begin{array}{c}-1.32^{* * *} \\
(0.395)\end{array}$ & & $\begin{array}{c}-1.35^{* * *} \\
(0.394)\end{array}$ \\
\hline Log-Likelihood & & -4493.0 & & -4489.5 \\
\hline
\end{tabular}


Table 8: Labor Market History Simulations within Sample Frame

\begin{tabular}{|c|c|c|c|}
\hline Heterogeneity & [Data] & $\begin{array}{l}\text { No } \\
(1) \\
\end{array}$ & $\begin{array}{l}\text { Joint } \\
(2) \\
\end{array}$ \\
\hline \multicolumn{4}{|c|}{ Simulating the data } \\
\hline Duration of Employment & [85.1] & 84.7 & 84.4 \\
\hline Duration of Unemployment & {$[34.9]$} & 34.3 & 35.0 \\
\hline Fraction of Employment Spells Ending with Quit & {$[0.25]$} & 0.21 & 0.25 \\
\hline Fraction of Time Spent Employed & {$[0.656]$} & 0.668 & 0.659 \\
\hline \multicolumn{4}{|c|}{ Effect of setting the UIC eligibility coefficient in employment hazard to zero } \\
\hline Change in Duration of Employment & & 3.5 & 11.3 \\
\hline Change in Duration of Unemployment & & 0.3 & 0.5 \\
\hline Change in Fraction of Time Spent Employed & & 0.007 & 0.027 \\
\hline \multicolumn{4}{|c|}{ Effect of lowering UIC entitlement from 39 to 26 weeks for all workers } \\
\hline Change in Duration of Employment & & 0.6 & 0.3 \\
\hline Change in Duration of Unemployment & & -2.4 & -2.8 \\
\hline Change in Fraction of Time Spent Employed & & 0.020 & 0.023 \\
\hline
\end{tabular}

All simulations use estimates accounting for future UIC claims. Column (1) is based on no-heterogeneity estimates from columns (1) and (3) of Table 5 and column (2) of Table 7 . Column (2) is based on the joint heterogeneity specifications from column (3) of Table 6. 


\section{IZA Discussion Papers}

No Author(s)

211
A. van Soest
M. Das
X. Gong

212 X. Gong

A. van Soest

P. Zhang

213 X. Gong

A. van Soest

E. Villagomez

214 X. Gong

A. van Soest

215 J. Ermisch

M. Francesconi

216 F. Büchel

217 J. Hansen

R. Wahlberg

218 C. Dustmann

A. van Soest

219 F. Kramarz

T. Philippon

220 W. A. Cornelius

E. A. Marcelli

221

C. Grund

222 W.P.M. Vijverberg

223 M. Rosholm

M. Svarer
Titel

A Structural Labour Supply Model with

Nonparametric Preferences

Sexual Bias and Household Consumption: A

Semiparametric Analysis of Engel Curves in Rural

China

Mobility in the Urban Labor Market: A Panel Data

Analysis for Mexico

Family Structure and Female Labour Supply in

Mexico City

The Effect of Parents' Employment on Children's

Educational Attainment

The Effects of Overeducation on Productivity in

Germany - The Firms' Viewpoint

Occupational Gender Composition and

Wages in Sweden

Parametric and Semiparametric Estimation in Models with Misclassified Categorical Dependent Variables

The Impact of Differential Payroll Tax Subsidies on Minimum Wage Employment

The Changing Profile of Mexican Migrants to the United States: New Evidence from California and Mexico

Wages as Risk Compensation in Germany

Betit: A Family That Nests Probit and Logit

Wages, Training, and Job Turnover in a SearchMatching Model

Using Panel Data on Income Satisfaction to Estimate the Equivalence Scale Elasticity
5

$11 / 00$

5

5

$12 / 00$

7

$12 / 00$

Area Date

$11 / 00$

$11 / 00$

$11 / 00$

$11 / 00$

$11 / 00$

$11 / 00$

$11 / 00$

$11 / 00$

$12 / 00$

$12 / 00$

3 
On the Identification of Relative Wage Rigidity

Dynamics: A Proposal for a Methodology on Cross-Section Data and Empirical Evidence for Poland in Transition

227 L. Locher

Immigration from the Eastern Block and the former Soviet Union to Israel: Who is coming when?

228 G. Brunello

S. Comi

C. Lucifora

The College Wage Gap in 10 European

229 R. Coimbra

L. Modesto

Fluctuations Choices and Earnings: An Empirical Study for Portugal

\section{Selection}

234 R. Rotte

Sozioökonomische Determinanten extremistischer 3 ropawahlen 1994 und 1999 
244 S. M. Fuess, Jr. Soviet Union: A Study of the Suicide Epidemic in the 1990s M. Millea

Pay and Productivity in a Corporatist Economy: 
258 M. Rosholm

The Times They Are A-Changin':

02/01

K. Scott

Organizational Change and Immigrant 
273 G. Saint-Paul

274 P. J. Pedersen

N. Smith

275 G. S. Epstein

T. Lecker

276 B. Amable

D. Gatti

277 R. Winter-Ebmer

278 T. M. Andersen

279 T. M. Andersen

280
P. Apps

R. Rees

281

G. Saint-Paul

282

J. Albrecht

A. Björklund

S. Vroman

283 M. Hagedorn

A. Kaul

V. Reinthaler

284 H. Rapoport

A. Weiss

285 J. Jerger

C. Pohnke

A. Spermann

286 M. Fertig

C. M. Schmidt
Dynamic Self-Selection

Distribution and Growth in an Economy with

5

$03 / 01$

Limited Needs

Unemployment Traps: Do Financial Dis-

3

03/01

incentives Matter?

Multi-Generation Model of Immigrant Earnings: $\quad 1$

$03 / 01$

Theory and Application

The Impact of Product Market Competition on

5

$03 / 01$

Employment and Wages

Evaluating an Innovative Redundancy-Retraining 6 Project: The Austrian Steel Foundation

$03 / 01$

Welfare Policies, Labour Taxation and Inter-

2

$04 / 01$ national Integration

Product Market Integration, Wage Dispersion

2

$04 / 01$ and Unemployment

Household Saving and Full Consumption over the Life Cycle

04/01

Information Technology and the Knowledge

5

04/01 Elites

Is There a Glass Ceiling in Sweden?

5

$04 / 01$

Welfare Analysis in a Schumpeterian Growth

7

$04 / 01$ Model with Capital

The Optimal Size for a Minority

$04 / 01$

Gut betreut in den Arbeitsmarkt?

5

04/01

Eine mikroökonometrische Evaluation der

Mannheimer Arbeitsvermittlungsagentur

First- and Second-Generation Migrants in

04/01 
287 P. Guggenberger

A. Kaul

M. Kolmar

288

D. A. Cobb-Clark

289

L. Cameron

D. A. Cobb-Clark

290 D. A. Cobb-Clark

M. D. Connolly

C. Worswick

291 R. T. Riphahn

292

E. Wasmer

293 D. Cobb-Clark

T. F. Crossley

294 Š. Jurajda
Efficiency Properties of Labor Taxation in a

3

04/01 Spatial Model of Restricted Labor Mobility

Getting Ahead: The Determinants of and Payoffs

5

$04 / 01$ to Internal Promotion for Young U.S. Men and Women

Old-Age Support in Developing Countries:

3

$04 / 01$ Labor Supply, Intergenerational Transfers and Living Arrangements

The Job Search and Education Investments of 1 Immigrant Families

Cohort Effects in the Educational Attainment of 1 Second Generation Immigrants in Germany: An Analysis of Census Data

Between-group Competition in the Labor Market

5 and the Rising Returns to Skill: US and France 1964-2000

Gender, Comparative Advantage and Labor

1

$05 / 01$ Market Activity in Immigrant Families

Estimating the Effect of Unemployment

3

05/01 Insurance Compensation on the Labor Market Histories of Displaced Workers 